Egyptian Poultry Science Journal

http://www.epsaegypt.com

ISSN: 1110-5623 (Print) - 2090-0570 (On line)

\title{
EFFECT OF USING FULL-FAT SOY-BEAN IN BROILER DIETS ON PERFORMANCE, CARCASS PARTS, MEAT COMPOSITION, BONE TRAITS AND ECONOMIC EFFICIENCY
}

\author{
A. I. El-Faham; Nematallah G. M. Ali; and M. A. M. Abdelaziz \\ Poult. Prod. Dep., Fac. of Agric., Ain Shams Univ., Egypt \\ Corresponding author: Mrwan Abdelaziz; E-mail: mrwanabdelaziz@agr.asu.edu.eg
}

Received: 01/07/2016 Accepted: 01/08/2016

\begin{abstract}
This experiment was conducted to determine the effect of adding full-fat soy-bean (FFSB) as a replacement of vegetable oil in isonitrogenous broiler diets on growth performance, carcass parts, meat composition, bone traits and economic efficiency. Four levels of FFSB representing 2 and $4 \%$ (T2), 4 and $6 \%$ (T3), 8 and $10 \%$ (T4) and 10 and $12 \%$ (T5) were used to replace soy-bean oil 2 and $4 \%$ (control, T1) during the starting and growing periods, respectively. A total number of 150 one-day-old Hubbard broiler chicks were divided equally into five groups. Each group comprised 30 birds in 3 replicates (10 chicks/ replicate). At the end of the experiment, 3 birds from each treatment were randomly selected and slaughtered for carcass, meat and tibia measurements. The results revealed no significant differences were observed among all five dietary treatments in body weight gain, feed consumption, feed conversion ratio and growth rate during the period from 0 to 5 weeks of age. Since, chicks fed (T3) or (T5) diets revealed best significant results in protein and energy conversion ratios during the period of 0 to 3 weeks of age compared with other dietary treatments. Concerning carcass and chemical composition of drum-stick meat, it is worth to note that chicks that fed (T3) or (T5) diets presented highest breast, and lowest thigh percentages compared with those fed other dietary treatments. While, highest crude protein and ash percentages with lowest crude fat percentages drum-stick meat, were recorded for chicks fed (T5) diet compared with other dietary treatments. Regarding tibia traits and composition, it was noted that chicks fed (T5) diet presented lowest figures (tibia length, breaking strength, dry weight, calcium \% and phosphorus \%) compared with those fed control (T1) diet. Economic evaluation showed that FFSB was economically efficient when included at levels of 8 and $10 \%$ in starter and grower diets, respectively without any adverse effect on growth performance or carcass and tibia traits of broiler chicks until 5 weeks of age.
\end{abstract}

Key Words: Broiler - Full-Fat Soy-Bean - Carcass and Tibia. 


\section{INTRODUCTION}

Poultry represents a significant part of animal production and contribute very large capacity of animal protein for human consumption. During the last three decades, poultry production in Egypt and many other developing countries has increased proportionally more than developed nations (FAO, 1991). Several reports indicated improved poultry performance and quality of produced meat by adding different dietary oil and fat sources to poultry diets. However each source or type of oil/ fat had a different effect on growth parameters and carcass quality (Ali et al., 2014; Ibrahim, 2005; Ghazalah et al., 2003; and ElHusseiny et al., 2000). Also, vegetable oils represent conventional energy sources, used in laying diets (El-Husseiny et al., 2002), Japanese quail diets (Ali et al., 2013), broiler diets (Abou El-Wafa et al., 2000) and diets of locally-developed (Montazah) broilers (Ibrahim, 2005). On the other hand, few investigators used untraditional fat sources (El-Husseiny et al., 2000), dry fat Ghazalah et al. (2007) and full-fat soy-bean (Subuh et al., 2002) as fat sources for energy to replace vegetable oils in formulating broiler diets. Full-fat soy-bean (FFSB) could provide both supplemental protein and energy in one integrated feed ingredient. Several studies dealt with the interrelationship between FFSB, soy-bean meal and vegetable oils as protein and energy sources in broiler diets, with variable results and conflicting findings about effects of using FFSB as a feed ingredient on broiler productive performance (Tammam, 2015; Monica et al., 2001; Subuh et al., 2002; Al-Shanti, 2003; Popescu and Criste, 2003; Salajpal et al., 2006; Demeterová, 2009; Al-Sardary, 2010; and El-Serwy, 1997). Tammam (2015) stated that inclusion of FFSB could completely replace soy-bean oil at 2, 3 and $4 \%$ in starter, grower and finisher broiler diets, respectively, without any adverse effect on growth performance, carcass or bone traits with significantly higher crude protein \% in thigh meat. Popescu and Criste (2003) found that, daily and total gain of broiler chicks fed FFSB diet was significantly greater than control group, and assured increased crude protein $\%$ of carcass meat with better ratios of fatty acids. Similar observations were reported by Al-Shanti (2003), who stated that feeding broiler diets containing 10\% FFSB in replacement of soy-bean oil and soybean meal resulted in improved broiler productive performance (body weight gain, feed conversion ratio and economic efficiency). Moreover, abdominal fat, blood concentrations of cholesterol and triglycerides, had significantly decreased as compared with control group. However, Leeson et al. (1987) included FFSB in broiler starter and finisher diets at a level of $30 \%$, and reported that growth performance was reduced during starter period. And so, the objective of this study was to evaluate effects of feeding graded levels of FFSB in replacement of soy-bean oil and soy-bean meal in starter and grower diets on performance, carcass portions, meat composition, bone measurements and economic efficiency of broiler chickens.

\section{MATERIALS AND METHODS}

This study was conducted at Agricultural Experiments and Research Station at Shalakan, Poultry Production Experimental Unit, Faculty of Agriculture, Ain Shams University.

Birds and housing: A total number of 150 one-day-old Hubbard broiler chicks were randomly divided into 5 groups in 3 replicates of 10 chicks each. Chicks of all experimental treatments were kept under similar hygienic and environmental conditions and vaccinated against common diseases. Floor brooders with gas heaters were used for rearing chicks. Feed and 
water were provided ad-libitum throughout the experimental period. The feeding system of experimental period was divided into 2 phases: starter (1 to 21 days) and grower (22 to 35 days).

Experimental diets: Five isonitrogenous diets were formulated at starting period. The experimental diets contained about 23 $\% \mathrm{CP}$ and 2900 to $3000 \mathrm{Kcal} / \mathrm{Kg}$ (Table 2), while at growing period, the corresponding diets contained about $21 \%$ $\mathrm{CP}$ and 2990 to $3180 \mathrm{Kcal} / \mathrm{Kg}$. In regard to experimental feed ingredients, extruded full-fat soy-bean (FFSB) was included at 2 $\%$ (T2), $4 \%$ (T3), $8 \%$ (T4) and $10 \%$ (T5) (starter diets), while, it was included at $4 \%$ (T2), $6 \%$ (T3), $10 \%$ (T4) and $12 \%$ (T5) (grower diets), at the expense of soy-bean oil, yellow corn grains and soy-bean meal. In addition, the control (T1) corn-soy-bean meal diet was totally free of FFSB. However, all nutrients were covered as recommended by tabulated data published by NRC (1994). Proximate analysis according to AOAC (1995) was done on samples from soy-bean meal and FFSB, as shown in Table (1).

Data collection: Feed consumption and weight gain were calculated at the end of each phase and then feed conversion ratio was calculated. Protein conversion ratio (PCR) and energy conversion ratio (ECR) were also calculated for each phase. The PCR was calculated as grams of protein intake per grams of weight gain, whereas the ECR was calculated as total ME intake / weight gain (gram). At the end of the experiment, 3 birds from each treatment were randomly selected and slaughtered, and data of carcass parts (breast, wings, thighs and drum-stick as percentage of live weight), deboned drum-stick muscle, tibia bone and skin calculated as\% of drum-stick weight, were recorded. Chemical composition of drum-stick meat and tibia bone were estimated. Tibia bone traits (Seedor index, Robusticity index and breaking strength) were also recorded. A production cost analysis and economic evaluation was carried out for all dietary treatments in an attempt to investigate effects of FFSB inclusion on feeding costs.

Statistical analysis: Data were statistically analyzed using the General Linear Model procedure of analysis (SAS, 2004). Duncan's multiple range test (Duncan, 1995), was used to test differences within means of treatments, while level of significance was set typically at minimum $(p \leq 0.05)$. The statistical model used for analyzing data was as following:

where:

$$
Y_{i j}=M+T_{i}+E_{i j}
$$

$\mathrm{Y}_{\mathrm{ij}}=$ individual observation; $\mathrm{M}=$ overall mean; $T_{i}=$ effect of treatment; $E_{i j}=$ random error

\section{RESULTS AND DISCUSSION}

Chemical analysis and nutritive value of full-fat soy-bean (FFSB): Results of proximate analysis (on dry weight basis) of FFSB used in this research in comparison to soy-bean meal (SBM) and soy-bean oil (SBO) are illustrated in Table (1). Analysis indicated that SBM was higher in crude protein $(44 \%)$ compared to FFSB $(36 \%)$. Ether extract was maximal in SBO (100\%) and about (18\%) in FFSB while SBM was $(0.8 \%)$. The highest metabolizable energy was in SBO $(9687 \mathrm{Kcal} / \mathrm{Kg})$, while SBM was the lowest $(2230 \mathrm{Kcal} / \mathrm{Kg})$ and FFSB was in between $(3950 \mathrm{Kcal} / \mathrm{Kg})$. As shown in Table (1), the calculated essential amino acids (methionine, cysteine and lysine) and macro elements such as calcium and phosphorus in SBM are relatively higher than those found in FFSB. These observations were in agreement with those reported by Buitrago (1992); Navarro et al. (1996); El-Serwy (1997) and Al-Shanti (2003).

Productive performance: The body weight gain, feed consumption, feed conversion ratio and growth rate of broilers as affected by dietary treatments are illustrated in Table (3). Responses of chicks fed diets containing FFSB showed that chicks fed diets containing higher FFSB 
levels (T4 or T5), maintained higher body weight gain than those fed lower levels (T2 or T3), being significantly similar to those fed control diet (T1). Moreover, addition of FFSB to experimental treatments led chicks to consume significantly equal amount of feed compared with those fed control diet and corresponding values ranged between 2559.32 and $2732.95 \mathrm{~g}$. In the same order, values of feed conversion ratio and growth rate indicated insignificant differences between chicks fed diets containing FFSB (T2: T5) compared with those fed control diet (T1). The best feed conversion ratio was detected for birds fed T5 diet (1.89). On the other hand, worst feed conversion ratio was found in chicks fed T4 diet (2.04) or T2 diet (1.98), without significant differences between all treatments. Moreover, feeding T5 diet gave better growth rate (1.88) compared to diets containing other levels of FFSB (T2: T4) or control diet (being the same figure, 1.87). Similar observations were reported by ElSerwy (1997) who concluded that, chicks fed diet containing heated full-fat soy-bean at a replacement ratio of $75 \%$ (soy-bean meal) attained an equal performance for weight gain and feed conversion ratio as those of control group. On the other hand, obtained results are in disagreement with those reported by Al-Shanti (2003), who found that chicks fed diets contained $10 \%$ of either extruded full-fat soy-bean or olive cake, had significantly higher weight gain values and better feed conversion ratio as compared to control group.

Protein and metabolizable energy conversion ratio: Impact of FFSB supplementation to broiler diets on protein conversion ratio (PCR) and metabolizable energy conversion ratio (ECR) are illustrated in Table (4). Effect of FFSB level in broiler diets was significant for PCR and ECR during the period; 0 to 3 weeks of age, (starter period). It is clear that, chicks fed T3 or T5 diets had better PCR and ECR values during starter period, while, chicks fed other dietary treatments
(T1, T2 or T4) had worse values (differences between T3 and T5 were not significant for PCR only). On the other hand, it was obvious (Table 4) that the effect of FFSB on PCR and ECR for broilers during growing and overall period was not significant compared with control (T1). Corresponding values for PCR ranged between 0.41 and 0.44 , while ECR ranged between 57.49 and 62.01 during overall experimental period (0-5 weeks). Alternatively, birds fed T5 diet gave insignificantly better figures when compared with other experimental treatments (T1: T4), to be 0.41 and 57.49 for PCR and ECR, respectively. In this regard, better efficiency in converting crude protein and energy per gram gain could be explained by relatively higher weight gain noticed in this group. In addition, the nature of FFSB oil had an adequate amount of unsaturated fatty acids which have been determined as essential for growth with a number of beneficial effects (Murray et al., 1991; and Koci et al., 1997).

Carcass traits: The results obtained for carcass traits are listed in Table (5). It was clearly noted that the inclusion of FFSB in broiler diets (T2: T5) had significant effects on some carcass parts compared with control diet. The corresponding values for breast $\%$ ranged between 33.41 and 36.41 $\%$, while thighs $\%$ ranged between 16.90 and $19.56 \%$. Moreover, chicks fed T5 or T3 diets showed higher breast $\%$ being 36.41 and $35.10 \%$, respectively and lower figures in thighs \% being 18.38 and 16.90 $\%$, respectively. In the same order, figures of wings and drum-stick percentages indicated insignificant differences between chicks fed diets containing FFSB (T2: T5) compared with those fed control diet (T1). Results in Table (5) also show drum-stick component parts. The percentages of drumstick skin in relation to body weight for broiler fed T5 diet reflected lower figures than those fed T3 diet. The corresponding figures were 0.51 versus $0.91 \%$. While, 
figures of muscle or bone (tibia) \% indicated insignificant differences between chicks fed different dietary treatments. AlShanti (2003) found that, higher values for proportional edible meat was observed with chicks fed diets contained $10 \%$ of either full-fat soy-bean or olive cake as compared with the control group. In contrary, ElSerwy (1997) and Tammam (2015) reported that no significant differences were observed among groups of chicks fed different levels of full-fat soy-bean either in carcass yield or relative weight of body organs, total edible parts, abdominal fat or other carcass cuts.

Chemical composition of drum-stick meat: Data for chemical composition of drum-stick meat are listed in Table (6). It was clearly noted that the inclusion of different levels of FFSB in broiler diets, had significant effects on studied parameters compared with control. In general, dry matter content was almost the same when chicks fed different dietary treatments. On the other hand, ash\% ranged between 2.01 and $4.14 \%$, while crude fat $\%$ ranged between 12.34 and $16.87 \%$ and crude protein ranged between 67.17 and $78.60 \%$. Moreover, chicks fed T3 diet showed lowest ash and crude protein percentages being 2.01 and $67.17 \%$, respectively. While, chicks fed T4 or T5 diets showed lower crude fat $\%$ being 12.73 and $12.34 \%$, respectively. These findings are in agreement with those obtained by Tammam (2015) who concluded that feeding FFSB to broilers, had significantly higher crude protein $\%$ and lower ether extract $\%$ in drum-stick meat compared with control group.

Tibia bone traits: Tibia measurements of slaughtered birds from different treatments are listed in Table (7). It is worth to note that chicks fed (T4) diet reflected higher tibia figures (length, width, Seedor index and breaking strength) compared with those fed other dietary treatments. No significant differences were found in all studied traits within experimental treatments except for tibia length. In that, tibia length ranged between 8.16 and $8.60 \mathrm{~cm}$, and chicks fed control (T1) or (T4) diets gave higher figures, while, chicks fed (T2) diet recorded lower figure. In the same order, corresponding values for tibia width ranged between 0.55 and $0.61 \mathrm{~cm}$, while, Seedor index ranged between 0.43 and 0.50 and breaking strength ranged between 131.14 and $191.53 \mathrm{~N}$. The differences were statistically insignificant. These findings are in agreement with those reported by Abdelhady et al. (2014), who reported that feeding broiler chicks low metabolizable energy diets, had significantly reduced tibia (length and width) while tibia weight, tibia breaking strength or tibia chemical composition (ash, calcium and phosphorus percentages) were not affected.

Tibia bone composition: Data of tibia chemical composition are summarized in Table (8). Dry tibia weight, tibia dry matter and ash percentages recorded significant differences within groups (T2: T5) as compared with control (T1). Dry matter\% for broiler fed (T2: T4) diets showed lower significant figures compared with those fed (T1 or T5) diets and corresponding values ranged between 43.54 and $47.59 \%$. In the same order, ash\% ranged between 20.43 and $25.68 \%$ and chicks fed T4 diet gave significantly lower figure. While, chicks fed T3 diet had significantly higher figure. No significant differences were observed on tibia calcium $\%$ and phosphorus $\%$ of birds fed (T2: T5) diets compared with control (T1). On the other hand, it is worth to note that inclusion of FFSB in broiler diets (T2: T5) revealed apparently insignificant linear reduction in calcium and phosphorus percentages in relation to FFSB inclusion levels. Chicks fed T5 diet reflected the lowest numerical calcium and phosphorus percentages compared with other treatments (T2: T4). However, calcium $\%$ decreased by $12 \% \quad(23.6 \%$ versus $20.67 \%$ ) compared with those fed T2 diet and phosphorus $\%$ showed similar trend $(19.74 \%$ versus $18.36 \%)$. These 
results are in agreement with those reported by other investigators (Abdelhady et al., 2014; and Leterrier et al., 1998). On the other hand, findings of the present study are in contrast with those obtained by Venäläinen et al. (2006), who stated that tibia ash, $\mathrm{Ca}$ and $\mathrm{P}$ contents in broilers given low ME diets were greater than those given higher ME diets.

Economic evaluation: Data for economic evaluation are listed in Table (9) based on recent prices of local market for feed ingredients and chicken carcasses. It was clear that using low levels of FFSB (T2 or T3 diets), had relatively decreased both feeding cost and total cost of chickens compared with those fed control diets. The best feeding cost per chick was calculated for chicks fed T3 diet compared with those fed control diet, and corresponding figures were (9.00 versus 9.66 L.E./ bird). The net income, as a subtraction of total cost out of selling income, showed that chicks fed T4 diet was more economical followed by those fed T3 diet, while those fed (T2 or T5) diet remained close to those of control group recording worse values. The relative economic efficiency showed greater improvement of chicks fed (T4 or T3) diets and with higher values of 19.47 and 14.09, respectively, when compared to chicks fed $\mathrm{T} 1$ diet. In addition, chicks fed (T2 or T5) diets showed reduction in relative economic efficiency by (4.31 and $5.62 \%$ ), respectively, compared with those of control group (T1, $100 \%$ ).

In general, it could be recommended that using FFSB in a partial replacement of soybean (meal and/ or oil) at inclusion rates of 8 or $10 \%$ in starter and grower diets, respectively, would be beneficial in achieving higher economic efficiency without any adverse effect on productive performance, carcass cuts or tibia traits of broiler chicks till 35 days of age. 
Table (1): Chemical composition of different soybean products

\begin{tabular}{|l|c|c|c|c|c|c|c|c|}
\hline \multicolumn{1}{|c|}{ Ingredients } & $\begin{array}{c}\text { ME } \\
\text { Kcal/ kg }\end{array}$ & $\begin{array}{c}\text { CP } \\
\text { \% }\end{array}$ & $\begin{array}{c}\text { EE } \\
\text { \% }\end{array}$ & $\begin{array}{c}\text { Ca } \\
\text { \% }\end{array}$ & $\begin{array}{c}\text { AP } \\
\mathbf{\%}\end{array}$ & $\begin{array}{c}\text { Lys } \\
\mathbf{\%}\end{array}$ & $\begin{array}{c}\text { Meth } \\
\mathbf{\%}\end{array}$ & $\begin{array}{c}\text { Cys } \\
\mathbf{\%}\end{array}$ \\
\hline Full-Fat Soybeans (36\%) & 3950 & 36 & 18 & 0.25 & 0.165 & 2.40 & 0.53 & 0.53 \\
Soybean Meal (44 \%) & 2230 & 44 & 0.8 & 0.29 & 0.195 & 2.69 & 0.62 & 0.66 \\
Soybean Oil & 9687 & - & 100 & - & - & - & - & - \\
\hline
\end{tabular}

ME: Metabolizable Energy; CP: Crude Protein; EE: Ether Extract; Ca: Calcium; AP: Available Phosphorus; Lys: Lysine; Meth: Methionine and Cys: Cystein

Table (2): Feed ingredients and calculated chemical analyses of experimental diets

\begin{tabular}{|c|c|c|c|c|c|}
\hline \multirow[t]{2}{*}{ Ingredients } & \multicolumn{5}{|c|}{ Dietary Treatments - Starter (0-21 days) } \\
\hline & 1 & 2 & 3 & 4 & 5 \\
\hline Soy-bean Oil & 2.00 & 0.00 & 0.00 & 0.00 & 0.00 \\
\hline Full-Fat Soy-bean $(36 \%)$ & 0.00 & 2.00 & 4.00 & 8.00 & 10.00 \\
\hline Soy-bean Meal (44\%) & 33.00 & 31.00 & 30.00 & 27.00 & 26.00 \\
\hline Corn (grains) & 55.00 & 57.00 & 56.00 & 55.00 & 54.00 \\
\hline Fixed Ingredients * & 10.00 & 10.00 & 10.00 & 10.00 & 10.00 \\
\hline \begin{tabular}{|c|} 
Total \\
\end{tabular} & 100 & 100 & 100 & 100 & 100 \\
\hline \multicolumn{6}{|c|}{ Chemical Analysis (Calculated) } \\
\hline $\mathrm{CP} \%$ & 23.01 & 22.94 & 23.05 & 22.93 & 23.04 \\
\hline ME Kcal/ Kg diet & 3000 & 2904 & 2924 & 2974 & 2993 \\
\hline Calcium $\%$ & 0.84 & 0.84 & 0.85 & 0.85 & 0.85 \\
\hline Available Phosphorus\% & 0.50 & 0.50 & 0.51 & 0.52 & 0.52 \\
\hline Lysine\% & 1.29 & 1.29 & 1.31 & 1.32 & 1.34 \\
\hline Methionine \& Cysteine $\%$ & 0.95 & 0.96 & 0.96 & 0.96 & 0.97 \\
\hline Price/ Ton (L.E.) & 3834 & 3700 & 3733 & 3768 & 3801 \\
\hline \multicolumn{6}{|c|}{ Dietary Treatments - Grower (21-35 days) } \\
\hline & 1 & 2 & 3 & 4 & 5 \\
\hline Soy-bean Oil & 4.00 & 0.00 & 0.00 & 0.00 & 0.00 \\
\hline Full-Fat Soy-bean (36\%) & 0.00 & 4.00 & 6.00 & 10.00 & 12.00 \\
\hline Soy-bean Meal (44\%) & 28.00 & 24.00 & 23.00 & 20.00 & 19.00 \\
\hline Corn (grains) & 58.00 & 62.00 & 61.00 & 60.00 & 59.00 \\
\hline Fixed Ingredients $*$ & 10.00 & 10.00 & 10.00 & 10.00 & 10.00 \\
\hline \begin{tabular}{|c|} 
Total \\
\end{tabular} & 100 & 100 & 100 & 100 & 100 \\
\hline \multicolumn{6}{|c|}{ Chemical Analysis (Calculated) } \\
\hline $\mathrm{CP} \%$ & 21.06 & 20.92 & 21.04 & 20.91 & 21.03 \\
\hline ME Kcal/ Kg diet & 3183 & 2991 & 3010 & 3060 & 3079 \\
\hline Calcium\% & 0.83 & 0.83 & 0.83 & 0.84 & 0.84 \\
\hline Available Phosphorus\% & 0.49 & 0.50 & 0.51 & 0.52 & 0.52 \\
\hline Lysine $\%$ & 1.17 & 1.16 & 1.18 & 1.20 & 1.21 \\
\hline Methionine \& Cysteine\% & 0.90 & 0.91 & 0.91 & 0.91 & 0.92 \\
\hline Price/ Ton (L.E.) & 3815 & 3547 & 3580 & 3615 & 3648 \\
\hline
\end{tabular}

Fixed Ingredients *; Corn Gluten Meal (62): $6.15 \%$; Mono-calcium phosphate: $1.80 \%$; Calcium Carbonate: $1.15 \%$; Lysine HCL: $0.20 \%$; Methionine hydroxy-analogue: $0.20 \%$; Salt $(\mathrm{NaCl}): 0.20 \%$ and Premix: $0.30 \%$. Each $3 \mathrm{Kg}$ of premix contains: Vit. A: $12000000 \mathrm{IU}$; Vit. D3: $2000000 \mathrm{IU}$; Vit. E: $10000 \mathrm{mg}$; Vit. K3: 2000 mg; Vit. $B_{1}: 1000 \mathrm{mg}$; Vit. $\mathrm{B}_{2}: 5000 \mathrm{mg}$; Vit. $\mathrm{B}_{6}: 1500 \mathrm{mg}$; Vit. $\mathrm{B}_{12}: 10 \mathrm{mg}$; Vit. Biotin: $50 \mathrm{mg}$; Choline chloride: $250000 \mathrm{mg}$; Pantothenic acid: $10000 \mathrm{mg}$; Nicotinic acid: $30000 \mathrm{mg}$; Folic acid: $1000 \mathrm{mg}$; Minerals: Mn: 60000 mg; Zn: 50000 mg; Fe: 30000 mg; Cu: 10000 mg; I: 1000 mg; Se: 100 mg and Co: 100 mg. 
Table (3): Effect of different dietary treatments on productive performance

\begin{tabular}{|c|c|c|c|c|c|c|}
\hline \multirow{2}{*}{ Items } & \multicolumn{6}{|c|}{ Treatments } \\
\hline & 1 & 2 & 3 & 4 & 5 & Sig \\
\hline $\begin{array}{l}\text { Initial body } \\
\text { weight }(\mathrm{g})\end{array}$ & $42.90 \pm 0.7$ 乏 & $43.33 \pm 0.49$ & $44.21 \pm 1.02$ & $43.77 \pm 0.37$ & $44.65 \pm 0.64$ & NS \\
\hline $\begin{array}{l}\text { Body weight } \\
\text { gain }(\mathrm{g})\end{array}$ & $1344.35 \pm 33.75$ & $1332.16 \pm 43.09$ & $1307.79 \pm 22.38$ & $1342.56 \pm 34.82$ & $1442.68 \pm 64.53$ & NS \\
\hline $\begin{array}{l}\text { Feed } \\
\text { consumption }(\mathrm{g})\end{array}$ & $2636.94 \pm 26.38$ & $2638.43 \pm 36.96$ & $2559.32 \pm 86.71$ & $2732.95 \pm 83.36$ & $2730.64 \pm 86.21$ & NS \\
\hline $\begin{array}{l}\text { Feed conversion } \\
\text { ratio (feed/gain) }\end{array}$ & $1.96 \pm 0.07$ & $1.98 \pm 0.03$ & $1.95 \pm 0.03$ & $2.04 \pm 0.19$ & $1.89 \pm 0.02$ & NS \\
\hline Growth rate & $1.87 \pm 0.01$ & $1.87 \pm 0.01$ & $1.87 \pm 0.01$ & $1.87 \pm 0.01$ & $1.88 \pm 0.01$ & NS \\
\hline
\end{tabular}

Sig. = Significance; NS = Non Significant.

Table (4): Effect of different dietary treatments on protein conversion ratio and energy conversion ratio

\begin{tabular}{|l|c|c|c|c|c|c|}
\hline \multirow{2}{*}{ Items } & \multicolumn{7}{|c|}{ Dietary Treatments } & Sig. \\
\cline { 2 - 7 } & $\mathbf{1}$ & $\mathbf{2}$ & $\mathbf{3}$ & $\mathbf{4}$ & $\mathbf{5}$ & \\
\hline & \multicolumn{7}{|c|}{ PCR: Protein conversion ratio (g protein/ g gain) } & $* *$ \\
\hline $0-3$ weeks & $0.37^{\mathrm{a}} \pm 0.01$ & $0.38^{\mathrm{a}} \pm 0.01$ & $0.35^{\mathrm{b}} \pm 0.01$ & $0.38^{\mathrm{a}} \pm 0.01$ & $0.35^{\mathrm{b}} \pm 0.01$ & $\mathrm{~N}$ \\
$4-5$ weeks & $0.48 \pm 0.03$ & $0.48 \pm 0.01$ & $0.50 \pm 0.02$ & $0.51 \pm 0.08$ & $0.47 \pm 0.01$ & $\mathrm{NS}$ \\
\hline $0-5$ weeks & $0.43 \pm 0.01$ & $0.43 \pm 0.01$ & $0.43 \pm 0.01$ & $0.44 \pm 0.04$ & $0.41 \pm 0.01$ & $\mathrm{NS}$ \\
\hline & \multicolumn{7}{|c|}{ ECR: Energy conversion ratio $(1000 \mathrm{Kcal} / \mathrm{g}$ gain) } & \\
\hline $0-3$ weeks & $49.01^{\mathrm{a}} \pm 0.24$ & $47.89^{\mathrm{a}} \pm 0.11$ & $45.17^{\mathrm{c}} \pm 0.57$ & $48.76^{\mathrm{a}} \pm 0.06$ & $46.30^{\mathrm{b}} \pm 0.43$ & $* *$ \\
$4-5$ weeks & $72.67 \pm 5.06$ & $68.78 \pm 2.39$ & $71.83 \pm 2.77$ & $75.27 \pm 2.41$ & $68.69 \pm 1.59$ & $\mathrm{NS}$ \\
$0-5$ weeks & $60.84 \pm 2.41$ & $58.33 \pm 1.26$ & $58.50 \pm 1.09$ & $62.01 \pm 6.17$ & $57.49 \pm 1.01$ & $\mathrm{NS}$ \\
\hline
\end{tabular}

$\mathrm{a}, \mathrm{b}, \mathrm{c}$ Means within the same row with different superscripts are significantly different; Sig. $=$ Significance; $* *=(\mathrm{p} \leq 0.01), \mathrm{NS}=$ Non Significant.

Table (5): Effect of different dietary treatments on some of carcass traits

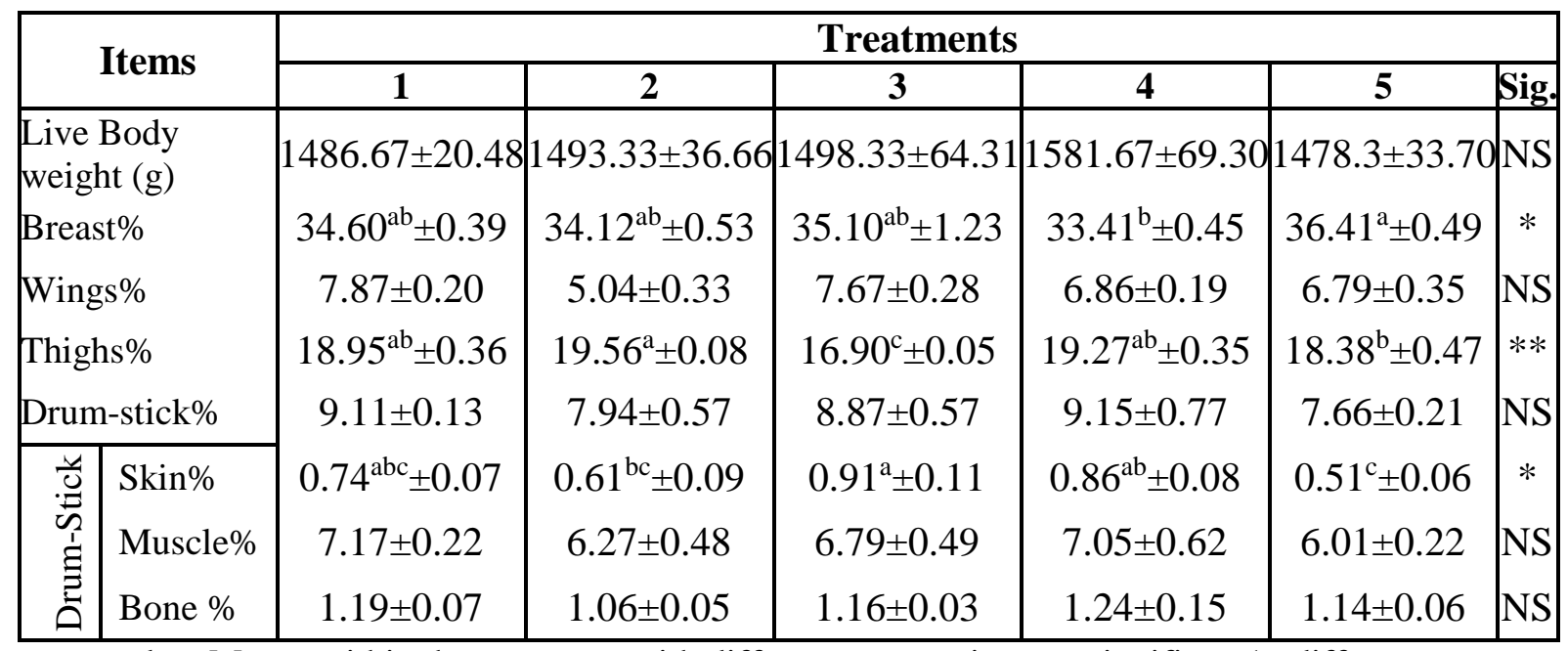

a, b, c Means within the same row with different superscripts are significantly different.

Sig. $=$ Significance; $* *=(p \leq 0.01) ; *=(p \leq 0.05) ;$ NS $=$ Non Significant. 
Table (6): Effect of different dietary treatments on drum-stick meat composition

\begin{tabular}{|l|c|c|c|c|c|c|}
\hline \multirow{2}{*}{\multicolumn{1}{|c|}{ Items }} & \multicolumn{7}{c|}{ Treatments } \\
\cline { 2 - 7 } & $\mathbf{1}$ & $\mathbf{2}$ & $\mathbf{3}$ & $\mathbf{4}$ & $\mathbf{5}$ & Sig. \\
\hline Dry matter\% & $26.31 \pm 0.70$ & $24.95 \pm 0.32$ & $26.28 \pm 0.48$ & $25.08 \pm 0.23$ & $25.51 \pm 0.36$ & $\mathrm{NS}$ \\
Ash\% & $3.43^{\mathrm{a}} \pm 0.40$ & $3.22^{\mathrm{a}} \pm 0.22$ & $2.01^{\mathrm{b}} \pm 0.39$ & $3.47^{\mathrm{a}} \pm 0.37$ & $4.14^{\mathrm{a}} \pm 0.41$ & $*$ \\
Crude fat\% & $16.87^{\mathrm{a}} \pm 1.09$ & $13.94^{\mathrm{ab}} \pm 1.53$ & $16.14^{\mathrm{a}} \pm 0.67$ & $12.73^{\mathrm{b}} \pm 0.58$ & $12.34^{\mathrm{b}} \pm 0.63$ & $*$ \\
Crude protein\% & $72.16^{\mathrm{ab}} \pm 1.97$ & $77.48^{\mathrm{a}} \pm 1.85$ & $67.17^{\mathrm{b}} \pm 4.68$ & $75.47^{\mathrm{a}} \pm 0.67$ & $78.60^{\mathrm{a}} \pm 0.93$ & $*$ \\
\hline
\end{tabular}

a, b, c Means within the same row with different superscripts are significantly different.

Sig. $=$ Significance $* *=(\mathrm{p} \leq 0.05) ;$ NS $=$ Non Significant.

Table (7): Effect of different dietary treatments on tibia bone traits

\begin{tabular}{|l|c|c|c|c|c|c|}
\hline \multirow{2}{*}{\multicolumn{1}{|c|}{ Items }} & \multicolumn{7}{|c|}{ Treatments } \\
\cline { 2 - 7 } & $\mathbf{1}$ & $\mathbf{2}$ & $\mathbf{3}$ & $\mathbf{4}$ & $\mathbf{5}$ & Sig. \\
\hline Tibia length $(\mathrm{cm})$ & $8.60^{\mathrm{a}} \pm 0.11$ & $8.16^{\mathrm{b}} \pm 0.12$ & $8.36^{\mathrm{ab}} \pm 0.06$ & $8.60^{\mathrm{a}} \pm 0.10$ & $8.20^{\mathrm{b}} \pm 0.05$ & $*$ \\
Tibia width $(\mathrm{cm})$ & $0.55 \pm 0.01$ & $0.55 \pm 0.02$ & $0.55 \pm 0.01$ & $0.61 \pm 0.06$ & $0.60 \pm 0.02$ & $\mathrm{NS}$ \\
Seedor Index $^{1}$ & $0.48 \pm 0.01$ & $0.43 \pm 0.01$ & $0.45 \pm 0.02$ & $0.50 \pm 0.05$ & $0.49 \pm 0.01$ & $\mathrm{NS}$ \\
Robusticity index $^{2}$ & $4.15 \pm 0.01$ & $4.10 \pm 0.07$ & $4.07 \pm 0.09$ & $4.04 \pm 0.12$ & $4.03 \pm 0.07$ & $\mathrm{NS}$ \\
Breaking strength $^{3}(\mathrm{~N})$ & $172.51 \pm 22.89$ & $146.38 \pm 7.34$ & $148.17 \pm 15.52$ & $191.53 \pm 29.91$ & $131.14 \pm 10.29$ & $\mathrm{NS}$ \\
\hline
\end{tabular}

$\mathrm{a}, \mathrm{b}, \mathrm{c}$ Means within the same row with different superscripts are significantly different.

Sig. $=$ Significance; $*=(\mathrm{p} \leq 0.05) ; \mathrm{NS}=$ Non Significant.

1: Seedor et al. (1991); 2: Reisenfeld (1972); 3: Crenshaw et al. (1981).

Table (8): Effect of different dietary treatments on tibia bone composition

\begin{tabular}{|l|c|c|c|c|c|c|}
\hline \multirow{2}{*}{ Items } & \multicolumn{7}{|c|}{ Treatments } \\
\cline { 2 - 7 } & $\mathbf{1}$ & $\mathbf{2}$ & $\mathbf{3}$ & $\mathbf{4}$ & $\mathbf{5}$ & Sig. \\
\hline Dry tibia weight\% & $0.30^{\mathrm{ab}} \pm 0.01$ & $0.25^{\mathrm{c}} \pm 0.01$ & $0.28^{\mathrm{bc}} \pm 0.01$ & $0.31^{\mathrm{a}} \pm 0.01$ & $0.27^{\mathrm{c}} \pm 0.01$ & $* *$ \\
Dry matter\% & $47.33^{\mathrm{a}} \pm 0.68$ & $44.83^{\mathrm{b}} \pm 0.79$ & $43.54^{\mathrm{b}^{\mathrm{b}}} \pm 1.06$ & $44.46^{\mathrm{b}} \pm 0.43$ & $47.59^{\mathrm{a}} \pm 0.79$ & $* *$ \\
Ash\% & $22.89^{\mathrm{ab}} \pm 2.28$ & $25.62^{\mathrm{a}} \pm 1.48$ & $25.68^{\mathrm{a}} \pm 0.76$ & $20.43^{\mathrm{b}} \pm 0.57$ & $25.81^{\mathrm{a}} \pm 1.21$ & $*$ \\
Calcium\% & $21.83 \pm 1.26$ & $23.60 \pm 2.22$ & $23.25 \pm 0.78$ & $21.98 \pm 1.18$ & $20.67 \pm 0.53$ & NS \\
Phosphorus\% & $19.69 \pm 0.44$ & $19.74 \pm 4.49$ & $19.18 \pm 3.29$ & $18.56 \pm 1.27$ & $18.36 \pm 1.64$ & NS \\
\hline
\end{tabular}

$\mathrm{a}, \mathrm{b}, \mathrm{c}$ Means within the same row with different superscripts are significantly different.

Sig. $=$ Significance $; *=(\mathrm{p} \leq 0.01) ; *(\mathrm{p} \leq 0.05) . \mathrm{NS}=$ Non Significant.

Table (9): Effect of different dietary treatments on some economic traits

\begin{tabular}{|l|c|c|c|c|c|}
\hline \multirow{2}{*}{\multicolumn{1}{|c|}{ Items }} & \multicolumn{5}{|c|}{ Treatments } \\
\cline { 2 - 6 } & $\mathbf{1}$ & $\mathbf{2}$ & $\mathbf{3}$ & $\mathbf{4}$ & $\mathbf{5}$ \\
\hline Average feed intake (Kg) & $2.63 \pm 0.02$ & $2.63 \pm 0.03$ & $2.56 \pm 0.08$ & $2.73 \pm 0.18$ & $2.73 \pm 0.08$ \\
Sold carcass weight (Kg) & $1.05 \pm 0.01$ & $1.01 \pm 0.04$ & $1.04 \pm 0.05$ & $1.09 \pm 0.06$ & $1.04 \pm 0.02$ \\
Feed Cost (LE) & $9.66 \pm 0.09$ & $9.19 \pm 0.12$ & $9.00 \pm 0.30$ & $9.70 \pm 0.64$ & $9.79 \pm 0.30$ \\
Total Cost (LE) \# & $14.66 \pm 0.09$ & $14.19 \pm 0.12$ & $14.00 \pm 0.30$ & $14.70 \pm 0.64$ & $14.79 \pm 0.30$ \\
Total Return (LE) * & $19.44 \pm 0.24$ & $18.61 \pm 0.95$ & $19.20 \pm 0.94$ & $20.28 \pm 1.10$ & $19.31 \pm 0.49$ \\
Net Return (LE) & $4.77 \pm 0.15$ & $4.42 \pm 0.93$ & $5.20 \pm 0.83$ & $5.58 \pm 1.60$ & $4.52 \pm 0.64$ \\
Economic Efficiency & $32.56 \pm 0.88$ & $31.16 \pm 6.59$ & $37.15 \pm 5.87$ & $38.90 \pm 11.95$ & $30.73 \pm 4.69$ \\
Relative Economic & $100.00 \pm 0.00$ & $95.69 \pm 20.24$ & $114.09 \pm 18.05$ & $119.47 \pm 36.71$ & $94.38 \pm 14.42$ \\
Efficiency & & &
\end{tabular}

\# Total Cost $=($ Feed Cost + price of one-day live chicks + incidental costs $) ; *$

According to the local price of $\mathrm{Kg}$ sold carcass which was $18.50 \mathrm{~L}$.E. 


\section{REFERENCES}

Abdelhady, A. Y. M.; Ibrahim, S. A.; ElFaham, A. I.; and Abdel-Azeem, F., 2014. Tibia characteristics and plasma minerals in broiler chicks fed different levels of metabolizable energy diets supplemented with microbial phytase. $7^{\text {th }}$ Inter. Poult. Conference, pp: 372384.

Abou El-Wafa, S.; El-Husseiny, O. M.; and Shabaan, M., 2000. Influence of different dietary oil and fat sources on boiler performance. Egypt. J. Poult. Sci., 20: 741-756.

Al-Shanti, H. A., 2003. Effect of using olive cake of extruded full-fat soy-bean in broiler chicks diets. Egypt. J. Poult. Sci., 23(1): 1-13.

Ali, N. G. M.; El-Daly, E. F.; El-Faham, A. I.; Ibrahim, S. A.; and Mohamed, M. E., 2014. Nutrition and physiological study on using of Residual oil (Fatty acids and distillated Fatty acids) in growing local chick diets. Egypt. J. Poult. Sci., 34 (1): 99-117.

Ali, N. G. M.; Ibrahim, S. A.; El-Faham, A. I.; Abdel-Fattah, S. A.; and Farag, S. E., 2013. Nutritional and economic evaluation of using non conventional fat sources in growing Japanese quail diets. Egypt. J. Nutr. Feeds, 16(2) (Special Issue): 445-452.

Al-Sardary, S. T., 2010. Performance of broiler chickens fed locally grown fullfat soybean based diets in Iraq. Iraqi J. Poult. Sci., 5: 111-125.

AOAC, 1995. Association of Official Analytical Chemists Official. methods of analysis $16^{\text {th }}$ Ed. Volume 2, Washington D.C., USA.

Buitrago, J. A., 1992. Soya integral as alimentación de aves. Boletín técnico de la Asociación Americana de la soya. Ediciones Atropos Ltd. Santa Fe de Bogotá, D.C., Colombia.

Crenshaw, T. D.; Peo, E. R.; Lewis, A. J. Jr.; and Moser, B. D., 1981. Tibia strength as a trait for assessing mineralization in swine: A critical review of techniques involved. J. Anim. Sci., 53: 827-835.

Demeterová, M., 2009. Performance of chickens fed diets containing full-fat soybean and natural humic compounds. Folia Veterinaria, 53(3): 151-153.

Duncan, D. B., 1955. Multiple range and Multiple F tests. Biometrics, 11: 1-42.

El-Husseiny, O. M.; Reda, M. A.; and Michael, M. A., 2000. Influence of dietary oil and calcium sources on broiler performance. Egypt. J. Poult. Sci., 20: 673-702.

El-Husseiny, O. M.; Soliman, A. Z.; Abd El-Esamee, M. O., and Omara, I. I., 2002. Influence of dietary lipid sources and levels on laying hen performance, egg quality and nutrients utilization. Egypt. J. Poult. Sci., 22: 763-791.

El-Serwy, A. A., 1997. Effect of the pelleting of diets containing different levels of raw or heated full fat soy-bean on broiler performance. Egypt. J. Poult. Sci., 17(1): 31-49.

FAO, 1991. Food and Agriculture Organization of the United Nations, FAO production yearbook, vol. 44, Rome, Italy.

Ghazalah, A. A.; Soliman, A. Z. M.; Boulous, N. Z.; and Mobarez, M. Samia, 2007. Effect of using dry fat on performance, Nutrients digestibility, carcass traits and blood constituents of broiler chicks. Egypt. J. Poult. Sci., 27 (2): 363-382.

Ghazalah, A. A.; Abdel Salam, F. E., Arafa, S. A.; and Sayed, M. A. M., 2003. The use of some vegetable oil and animal fat sources for feeding broilers. Egypt. J. Nut. Feeding, 6 (special issue): 27 (abstr.).

Ibrahim, S. A., 2005. Effect of different dietary oils on the performance and carcass characteristics of silver Montazah growing chicks. J. Agric. Sci. Mansoura Univ., 30(8): 4439-4449. 
Koci, S.; Kociova, Z.; Ceresnakova, Z.; Palanska, O.; and Matrai, T., 1997. The effect of full fat extruded soya on the performance and product quality in layers and broiler chickens. Zivocisna Vyroba, 42: 67-72.

Leeson, S.; Atteh, J. O.; and Summers, J. D., 1987. Effects of increasing dietary levels of commercially heated soy-beans on performance, nutrient retention and carcass quality of broiler chickens. Can. J. Anim. Sci., 67: 821-828.

Leterrier, C.; Rose, N.; Constantin, P.; and Nys, Y., 1998. Reducing growth rate of broiler chickens with a low energy diet does not improve cortical bone quality. Br. Poult. Sci. 39(1): 2430.

Monica, P.; Iofciu, A.; Grossu, D.; and Iiescu, M., 2001. Efficiency of toasted fullfat soybeans utilization in broiler feeding. Archiva Zootechnica, 6: 121124.

Murray, R. K.; Mayes, P. A.; Granner, D. K.; and Rodwell, V. W., 1991. Harper's Biochemistry. 22 $2^{\text {nd }}$ Ed., Appleton \& Lange, Norwalk, Connecticut Los Altos, California.

Navarro, H.; Forat, M.; Casarin, A.; López, C.; and Miles, R., 1996. The use of high levels of fullfat soy beans in broiler rations. In $2^{\text {nd }}$ international fullfat soya conference. American Soybean Association. Budapest, Hungary. pp: 288- 292.

NRC, 1994. National Research Council. Nutrient Requirements of Poultry 9th ed. Composition of poultry feedstuffs. National Academy Press, Washington, DC, USA. Pp: 61-75.
Popescu, A.; and Criste, R., 2003. Using full fat soybean in broiler diets and its effect on the production and economic efficiency of fattening. J. Cent. Euro. Agric., 4: 167-174.

Reisenfeld, A., 1972. Metatarsal robusticity in bipedal rats. Amer. J. Phys. Anthr., 40: 229-234.

Salajpal, K.; Grbesa, D.; Kaps, M.; Kis, G.; and Karolyi, D., 2006. Effect of added copper and full fat soybean meal on growth performance and carcass properties in broiler chickens. Acta Agraria Kaposváriensis, 10(2): 207-213.

SAS Institute, 2004. JMP Statistics and Graphics Guide version 3.1. SAS Institute, Cary, NC. USA.

Seedor, J. G.; Quarruccio, H. A.; and Thompson, D. D., 1991. The biophosphonate alendronate (MK-217) inhibits tibia loss due to ovariectomy in rats. J. Tibia Min. Res., 6: 339-346.

Subuh, A. M. H.; Motl, M. A.; Fritts, C. A.; and Waldroup, P. W., 2002. Use of various ratios of extruded fullfat soybean meal and dehulled solvent extracted soy-bean meal in broiler diets. Int. J. Poult. Sci., 1: 9-12.

Tammam, A. M., 2015. Nutritional evaluation of some untraditional feedstuffs in growing chick diets. M.Sc. Thesis, Faculty of Agriculture, Ain Shams University.

Venäläinen, E.; Valaja, J.; and Jalava, T., 2006. Effects of dietary metabolisable energy, calcium and phosphorus on bone mineralisation leg weakness and performance of broiler chickens. Br. Poult. Sci., 47(3): 301310 . 


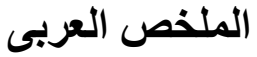

تأثير إستخدام فول الصويا كامل الدهن فى علائق بدارى التسمين على الأداء الإنتاجى، قطعيات

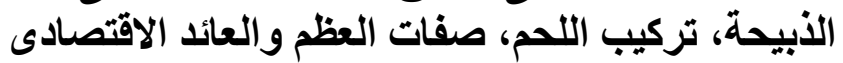

أحمد إبراهيم سليمان الفحام؛ نعمة الله جمال الدين محمد على؛ مروان إندان عبدالعزيز محمود عبدالعزيز

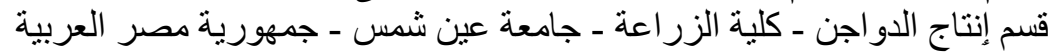

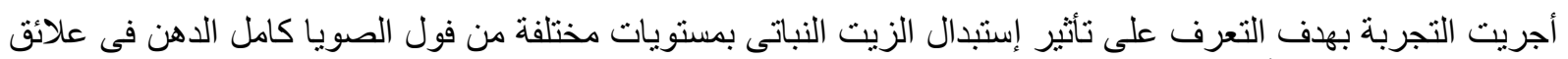

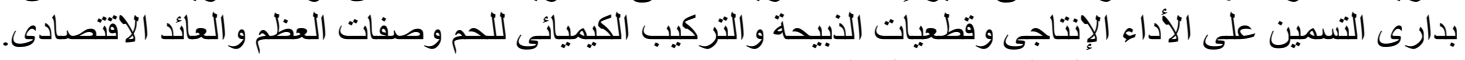

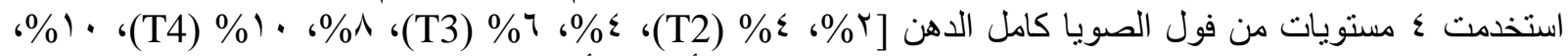

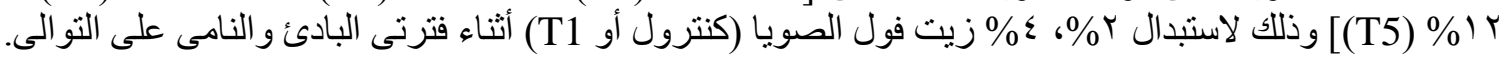

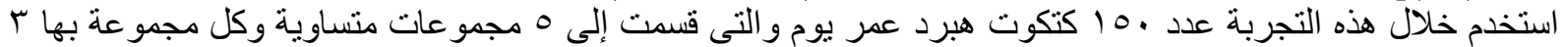

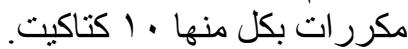

فى نهاية التجربة (عمر هب يوم) تم إختيار r طيور من كل معاملة عشو ائباً لدر اسة القياسات المختلفة للذبيحة

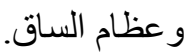

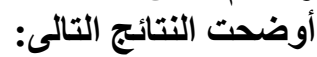

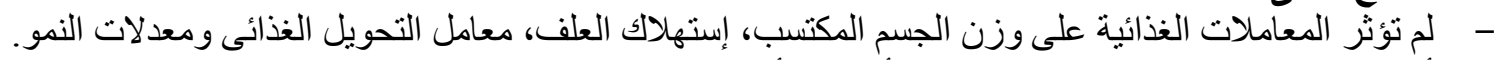

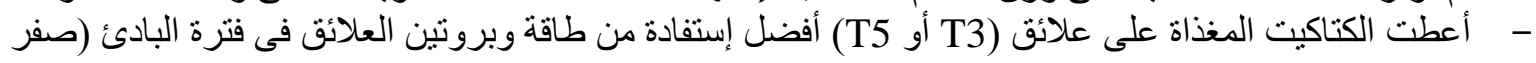

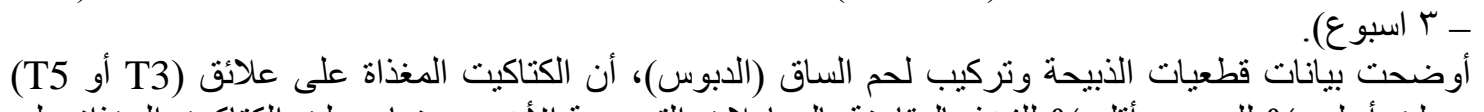

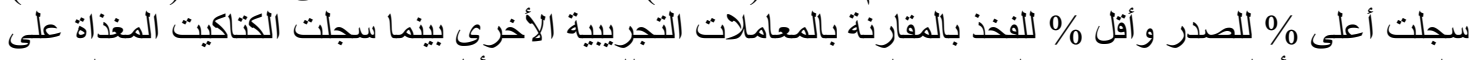

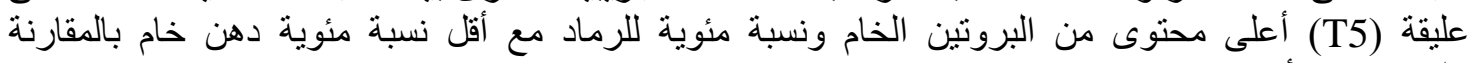

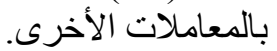

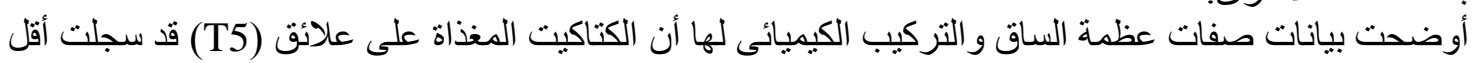

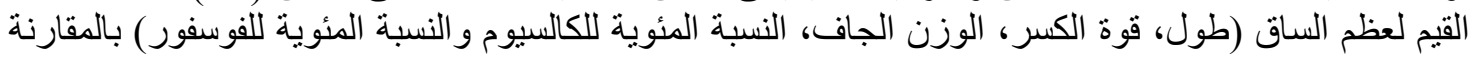
بمعاملة الكنترول.

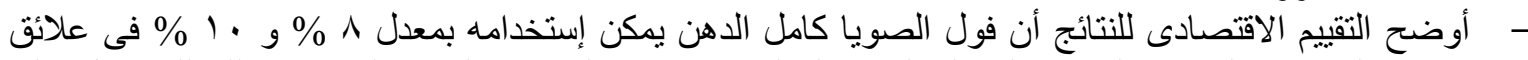

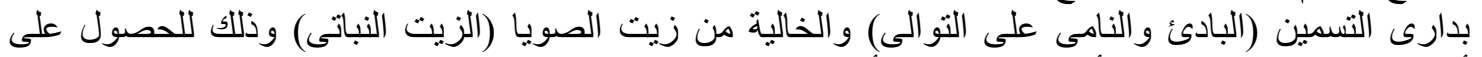

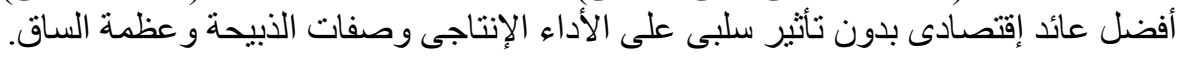

